\title{
FLAVONOIDS FROM Stachys annua GROWING IN AZERBAIJAN
}

\author{
I. S. Movsumov, ${ }^{1}$ E. A. Garayev, ${ }^{1 *}$ B. Baghdikian, ${ }^{2}$ F. Mabrouki, ${ }^{2}$ G. Herbette, ${ }^{3}$ E. Ollivier, ${ }^{2}$ T. A. Suleimanov, ${ }^{1}$ and \\ E. E. Garayev 1,2
}

1) Azerbaijan Medical University, 21 A. Bakikhanov St., Baku, AZ 1000, Azerbaijan, e-mail: eldargar@mail.ru;

2) Aix-Marseille Univ. IMBE, Laboratoire de Pharmacognosie et Ethnopharmacologie, Faculte de Pharmacie, 27 Boulevard Jean Moulin, CS30064,

13385 Marseille Cedex 5, France;

3) Spectropole, FR1739, Aix-Marseille Universite, Campus Scientique Saint Jerome, Service 511, 13397 Marseille Cedex 20, France, e-mail: gaetan.herbette@univ-amu.fr.

Translated from Khimiya Prirodnykh Soedinenii, No. 2, March-April, 2018, pp. 217-218. Original article submitted July 13, 2017.

The new acylated flavonoid bioside 4'-O-methylisoscutellarein-7-O-[4'"'-O-acetyl]allopyranosyl-(1 $\rightarrow 2)$-glucopyranoside (1) was isolated from the aerial parts of Stachys annua L. (Lamiaceae). Subterranean organs yielded for the first time 4'O-methylisoscutellarein (2) and 4'-O-methylisoscutellarein-7-O-[6"-O-acetyl]allopyranosyl-(1 $\rightarrow 2)$-glucopyranoside (3).

Chemical structures of the isolated compounds were elucidated using NMR spectroscopy.

Keywords: Stachys annua, Lamiaceae, new acylated bioside, annuoside.

In continuation of the search for potential new sources of biologically active compounds [1], we studied the aerial and subterranean organs of Stachys annua L. from the flora of Azerbaijan.

Previously, several Stachys species including S. аппиа from Ukraine, Azerbaijan, and European countries were incompletely studied [2]. Earlier, we isolated from the aerial parts of $S$. annua $\beta$-sitosterol, ursolic acid, and 4'-O-

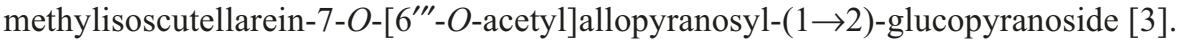

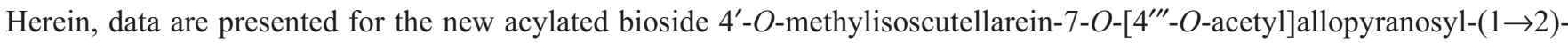
glucopyranoside (annuoside, 1) from the aerial part and $4^{\prime}-O$-methylisoscutellarein (2) and $4^{\prime}$ - $O$-methylisoscutellarein- 7-O$\left(6^{\prime \prime \prime}\right.$-O-acetyl)allopyranosyl-( $\left.1 \rightarrow 2\right)$-glucopyranoside $(3)$ from the subterranean organs of S. annua.

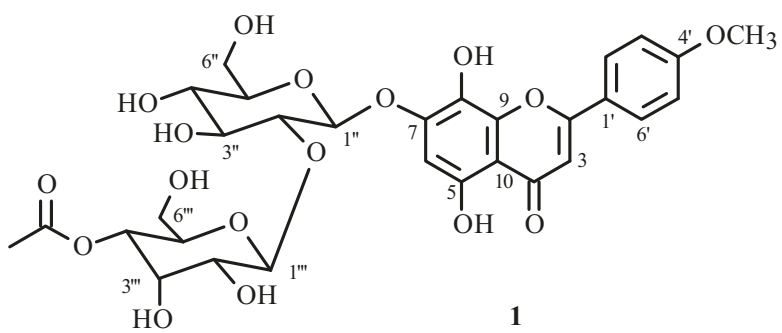

Acid hydrolysis of 1 produced the aglycon, acetic acid, D-glucose, and D-allose.

PMR spectra showed resonances for aromatic-ring protons at $\delta 8.2-6.0 \mathrm{ppm}$. Correlations were observed in the COSY spectrum between $\mathrm{H}-1^{\prime \prime}-\mathrm{H}-2^{\prime \prime}-\mathrm{H}-3^{\prime \prime}-\mathrm{H}-4^{\prime \prime}-\mathrm{H}-5^{\prime \prime}$ and $\mathrm{H}-1^{\prime \prime \prime}-\mathrm{H}-2^{\prime \prime \prime}-\mathrm{H}-3^{\prime \prime \prime}-\mathrm{H}-4^{\prime \prime \prime}-\mathrm{H}-5^{\prime \prime \prime}$ and corresponded to ring protons of the two sugars.

Resonances for anomeric protons could be seen in the HMBC spectrum. A correlation between $\mathrm{H}-1^{\prime \prime}$ ( $\left.\delta 5.17 \mathrm{ppm}\right)$

and C-7 ( $\delta$ 151.0) confirmed that the first sugar was bonded to C-7. Two correlations between H-2" $(\delta 3.63)$ and C-1"' $(\delta 101.4)$ in addition to $\mathrm{H}-1^{\prime \prime \prime}(\delta 4.97)$ and $\mathrm{C}-2^{\prime \prime}(\delta 81.7)$ confirmed that the second sugar was bonded to the first at C-2". The HMBC spectrum established that the $\mathrm{OCH}_{3}$ group $(\delta 3.87)$ was situated on $\mathrm{C}-4^{\prime}(\delta 162.3)$; the $\mathrm{CH}_{3}(\delta 1.99)$, to $-\mathrm{COO}(\delta 169.4)$; the methyl ester $-\mathrm{COOCH}_{3}$, to $\mathrm{C}-4^{\prime \prime \prime}(\delta 4.53)$. 
The aglycon had the formula $\mathrm{C}_{16} \mathrm{H}_{12} \mathrm{O}_{6}, \mathrm{mp} 272-274^{\circ} \mathrm{C}(\mathrm{EtOH})$, and $R_{f} 0.81$. The physicochemical and chemical properties and chromatographic and spectroscopic data for the aglycon of annuoside identified it as 4'-O-methylisoscutellarein.

\section{EXPERIMENTAL}

General Comments. Chromatography used Filtrak FN5 paper and solvent system $n$-BuOH-HOAc- $\mathrm{H}_{2} \mathrm{O}(4: 1: 5,1)$. UV spectra were recorded on an Agilent Technologies Cary 60 UV-Vis instrument; NMR spectra, on a Bruker AM-600 spectrometer; melting points, on a CMP 20 apparatus.

Isolation of Glavonoids from the Aerial Part of S. Annua. Raw material was collected in June 2015 in the vicinity of Shamakhi, Republic of Azerbaijan. Air-dried and ground aerial plant parts (1.0 kg) were extracted (3×) with EtOH (80\%) at room temperature. The extracts were combined and evaporated in vacuo to a watery residue that was worked up sequentially with hexane, $\mathrm{CHCl}_{3}$, and EtOAc.

Recrystallization from aqueous EtOH of the EtOAc extract afforded 4'-O-methylisoscutellarein-7-O-(6"' $-O$ acetyl)allopyranosyl-(1 $\rightarrow 2)$-glucopyranoside [3] and compound 1, which was called annuoside [3].

Annuoside (1), $\mathrm{C}_{30} \mathrm{H}_{34} \mathrm{O}_{17}$, greenish-yellow crystals; soluble in aqueous EtOH, DMF, and Py; poorly soluble in EtOH and $\mathrm{H}_{2} \mathrm{O}$; insoluble in $\mathrm{CHCl}_{3}$ and EtOAc; $\mathrm{mp} 176-178^{\circ} \mathrm{C}\left(\mathrm{H}_{2} \mathrm{O}\right), R_{f} 0.59 .{ }^{1} \mathrm{H}$ NMR spectrum $\left(600 \mathrm{MHz}, \mathrm{DMSO}_{6}, \delta\right.$, ppm, J/Hz): $8.11\left(2 \mathrm{H}, \mathrm{d}, \mathrm{J}=8.8, \mathrm{H}-2^{\prime}, 6^{\prime}\right), 7.14\left(2 \mathrm{H}, \mathrm{d}, \mathrm{J}=8.8, \mathrm{H}-3^{\prime}, 5^{\prime}\right), 6.92(1 \mathrm{H}, \mathrm{s}, \mathrm{H}-3), 6.64(1 \mathrm{H}, \mathrm{s}, \mathrm{H}-6), 5.17(1 \mathrm{H}, \mathrm{d}$, $\left.\mathrm{J}=7.7, \mathrm{H}-1^{\prime \prime}\right), 4.97\left(1 \mathrm{H}, \mathrm{d}, \mathrm{J}=7.7, \mathrm{H}-1^{\prime \prime \prime}\right), 4.53\left(1 \mathrm{H}, \mathrm{dd}, \mathrm{J}=10.2,2.5, \mathrm{H}-4^{\prime \prime \prime}\right), 4.09$ (1H, br.t, J = 2.8, H-3"' ), 3.87 (3H, s, $\left.\mathrm{OCH}_{3}\right), 3.86\left(1 \mathrm{H}, \mathrm{m}, \mathrm{H}-5^{\prime \prime \prime}\right), 3.73\left(1 \mathrm{H}, \mathrm{m}, \mathrm{H}-6^{\prime \prime}\right), 3.63\left(1 \mathrm{H}, \mathrm{dd}, \mathrm{J}=9.0,7.7, \mathrm{H}-2^{\prime \prime}\right), 3.51\left(1 \mathrm{H}, \mathrm{m}, \mathrm{H}-3^{\prime \prime}\right), 3.48\left(1 \mathrm{H}, \mathrm{m}, \mathrm{H}-6^{\prime \prime}\right)$, $3.46\left(1 \mathrm{H}, \mathrm{m}, \mathrm{H}-5^{\prime \prime}\right), 3.27$ (1H, m, H-6"'), 3.25 (1H, m, H-4"), 3.22 (1H, m, H-2"'), 3.23 (1H, m, H-6"'), 1.99 (s, OAc). ${ }^{13} \mathrm{C}$ NMR spectrum (150 MHz, DMSO-d 6 , $\delta$, ppm): 163.5 (C-2), 103.4 (C-3), 182.2 (C-4), 152.3 (C-5), 98.1 (C-6), 151.0 (C-7), 126.8 (C-8), 144.1 (C-9), 104.8 (C-10), 122.8 (C-1'), $128.3\left(\mathrm{C}-2^{\prime}, 6^{\prime}\right), 114.4\left(\mathrm{C}-3^{\prime}, 5^{\prime}\right), 162.3\left(\mathrm{C}-4^{\prime}\right), 55.4\left(\mathrm{OCH}_{3}\right), 98.9$

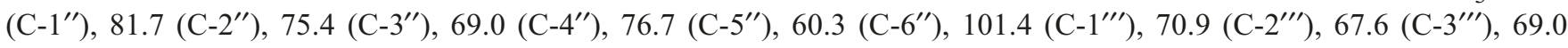
(C-4"') 71.6 (C-5'"'), 59.6 (C-6"'), 20.8, 169.4 (OAc) [3].

Isolation of Flavonoids from Subterranean Organs of S. Annua L. Ground and air-dried subterranean organs $(0.8 \mathrm{~kg})$ were extracted $(3 \times)$ with $\mathrm{EtOH}(80 \%)$ at room temperature. The combined extracts were evaporated in vacuo to an aqueous residue that was worked up sequentially with hexane, $\mathrm{CHCl}_{3}$, hexane-EtOAc, and EtOAc.

Recrystallization of the hexane-EtOAc extract from aqueous EtOH produced 2 (4'-methoxyisoscutellarein), $\mathrm{C}_{16} \mathrm{H}_{12} \mathrm{O}_{6}$, $\mathrm{mp} 270-272^{\circ} \mathrm{C}, R_{f} 0.81$. Alkaline hydrolysis of 2 formed 4-methoxybenzoic acid [4].

Recrystallization of the EtOAc extract from EtOH produced 3, acid hydrolysis $\left(5 \% \mathrm{H}_{2} \mathrm{SO}_{4}, 5 \mathrm{~h}\right)$ of which cleaved 3 into the aglycon, $\mathrm{AcOH}$, D-glucose, and D-allose. Aglycon, $\mathrm{C}_{16} \mathrm{H}_{12} \mathrm{O}_{6}, \mathrm{mp} 270-272^{\circ} \mathrm{C}(\mathrm{EtOH}), R_{f} 0.81$. Compound 3 was isolated earlier from the subterranean organs of $S$. аппиа [5].

\section{REFERENCES}

1. $\quad$ Flora of Azerbaijan [in Russian], Vol. VI, Baku, 1957, 646 pp.

2. Plant Resources. Flowering Plants, Their Chemical Compositions, and Use. Families Hippuridaceae-Lobeliaceae [in Russian], Nauka, St. Petersburg, 1991, 197 pp.

3. D. C. Albach, R. J. Grayer, S. R. Jensen, F. Ozgokce, and N. C. Veitch, Phytochemistry, 64 (7), 1295 (2003).

4. N. F. Komissarenko, A. I. Derkach, I. P. Sheremet, I. P. Kovalev, and V. G. Gordienko, Chem. Nat. Compd., 14, 445 (1979).

5. I. S. Movsumov, D. Yu. Yusifova, T. A. Suleimanov, V. Mahiou-Leddet, G. Herbette, B. Baghdikian, E. E. Garayev, E. Ollivier, and E. A. Garayev, Chem. Nat. Compd., 52, 324 (2016). 